\title{
Public Debt Sustainability and Management in a Compound Option Framework
} Jorge A. Chan-Lau and André O. Santos 


\title{
IMF Working Paper
}

Western Hemisphere and Monetary and Capital Markets Departments

\section{Public Debt Sustainability and Management in a Compound Option Framework}

\author{
Prepared by Jorge A. Chan-Lau and André O. Santos ${ }^{1}$ \\ Authorized for distribution by Robert Rennhack and Inci Ötker-Robe
}

January 2010

\begin{abstract}
This Working Paper should not be reported as representing the views of the IMF. The views expressed in this Working Paper are those of the author(s) and do not necessarily represent those of the IMF or IMF policy. Working Papers describe research in progress by the author(s) and are published to elicit comments and to further debate.
\end{abstract}

This paper introduces the Asset and Liability Management (ALM) compound option model. The model builds on the observation that the public sector net worth in a multi-period setting corresponds to the value of an option on an option on total government assets. Hence, the ALM compound option model is better suited for analyzing and evaluating the risk profile of public debt than existing one-period models, and is especially useful for analyzing the soundness of exit strategies from the large fiscal expansions undertaken by G-20 countries in the wake of the recent financial crisis. As an illustration, the model is used to analyze the risk profile and sustainability of Australia's public debt under different policies.

JEL Classification Numbers:C15, E62, F34, G12

Keywords: Asset-liability management, debt management, default risk, Australia

Author's E-Mail Addresses: $\quad$ jchanlau@,imf.org, asantos2@,imf.org

\footnotetext{
${ }^{1}$ We are grateful to many colleagues, especially Robert Rennhack, Inci Otker-Robe, and Christian B. Mulder, for helpful discussions and comments on the concept of public sector net worth and the compound option model. Any errors or omissions are the authors' sole responsibility. An abridged version of this paper was published in G.

Gregoriou, 2009. The VaR Modeling Handbook, (New York: McGraw Hill).
} 
I. Sound Public Debt Management: From Policy to Practical Implementation. 3

II. The ALM Compound Option Model: Incorporating Insights from Macro- and Option-based Models

A. Advantages Over One-Period Option-Based Models .............................................5

B. Advantages Over Macro-Based Models .........................................................6

III. The Government Balance Sheet and Net Worth ........................................................6

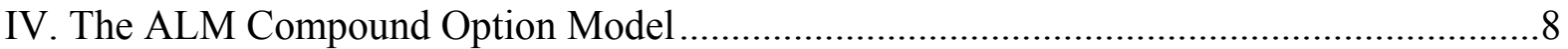

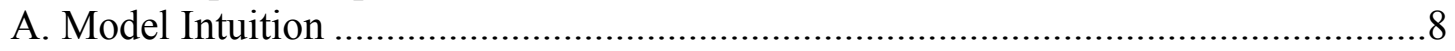

B. The ALM Compound Option Model: The Two-Period Case ...................................9

C. Solving the ALM Compound Option Model ........................................................ 14

D. The Role of Fiscal Policy and Asset and Liability Management...........................16

V. Application to Australia's Government Debt and Unfunded Superannuation

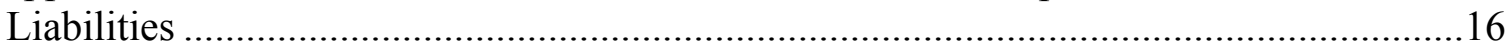

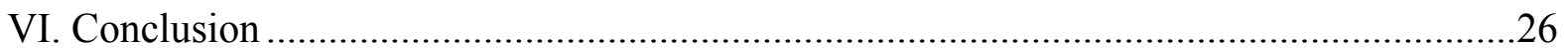

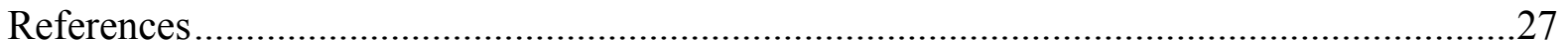

Tables

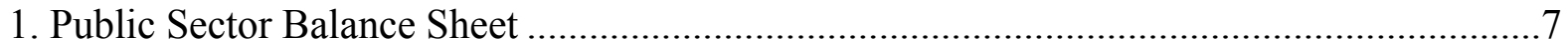

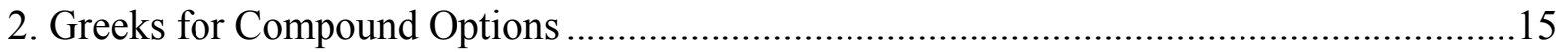

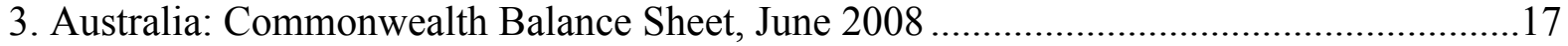

4. Australia: LSCM Simulation Results, June 2008 .......................................................21

Figures

1. Australia: Commonwealth Debt Service and Superannuation Benefits, End-June 2009 ....20

2. Australia: Commonwealth Probabilities of Default, End-June 2008. 


\section{Sound Public Debt Management: From Policy to Practical Implementation}

The two past decades have witnessed profound changes in the way countries manage their public debt. Foremost among the changes has been increased reliance on arm's-length financing through the issuance of government bonds, denominated either in foreign or domestic currency, in both international and domestic markets.

The dominance of arm's-length financing has been supported by several factors. On the one hand, the rapid growth of assets under management of institutional investors, especially superannuation funds, has created a stable investor base for government securities. On the other hand, public debt issuance has been facilitated by the adoption and implementation of sound macroeconomic and prudent fiscal policies. These policies have enabled governments not only to gain access to international markets, but also to be successful in establishing domestic government bond markets. ${ }^{2}$

Governments in G-20 countries have benefited from deep and liquid bond markets. In the wake of the financial crisis, governments have undertaken substantial fiscal expansion to prop up domestic financial institutions and soften the impact of the crisis on economic activity. While liquid government bond markets have been crucial for financing governments' fiscal expansion, the increased debt burden suggests the need for carefully planned exit strategies to keep the risks associated with public debt manageable.

Sound management of the risks of public debt rests on a number of sound principles based on accepted good practice. The principles, advanced by the IMF and the World Bank, state that (1) the objectives of debt management should be aligned with those of monetary and fiscal policy; (2) adequate transparency and accountability should be enforced through the disclosure of relevant risk measures and the allocation of responsibilities; (3) the institutional framework should clarify the legal issues related to debt management, ensure clear roles and responsibilities, and develop an adequate data framework; (4) the debt structures should be easy to monitor and cost-efficient, while minimizing liquidity and repayment risk; (5) an appropriate risk-management framework should be in place to account for the contingent liabilities of the government; and (6) the debt-management strategy should foster an efficient government securities markets.

Currently, there is wide agreement among government and multilateral institutions on the merits of the principles listed above. Sound public debt management, however, is ultimately an operational issue. In the absence of tools for the practical implementation of the principles, especially those related to the risk management of the public debt structure (Principles 4 and 5), the principles become just one more policy wish list with minimal

\footnotetext{
${ }^{2}$ Government bond markets, in turn, have fostered the development of domestic private securities markets. See International Monetary Fund (2002), Chapter 4, for details.
} 
impact on the day-to-day practice of public debt management. It becomes imperative, therefore, to provide debt managers with practical tools to meet the high standards set by the policy guidelines. Given the ongoing financial crisis with large government interventions funded with debt, it has become urgent to develop these tools.

In response to the need for practical tools that bridge the gap between policy goals and practical implementation, we introduce the Asset and Liability Management (ALM) compound option model. The ALM compound option model relies on (i) the compound options approach to credit risk analysis (Geske, 1977), and (ii) the intertemporal macroeconomic approach to debt sustainability, as it accounts for the fact that sovereign debt profiles involve multiple debt payments instead of a single debt payment. The model is useful not only for public debt management, but also for debt sustainability analysis, assetliability management in financial institutions, and for fixed income investors interested in establishing price benchmarks for sovereign debt. Therefore, the model provides a valuable tool to assess exit strategies from the large fiscal expansions financed with public debt in the wake of the recent financial crisis.

The structure of the remainder of the paper is as follows. Section II explains the advantages of the ALM compound option model over alternatives. Section III explains how to measure the debt repayment capacity of the public sector in a way that is consistent with the 2001 IMF Government Finance Statistics (GFS) definitions of the government balance sheet and net worth. Section IV presents the ALM compound option model, which is then used in section $\mathrm{V}$ to analyze the risk profile of Australia's public debt and unfunded superannuation liabilities. Section VI concludes.

\section{THE ALM COMPOUND OPTION MODEL: INCORPORATING INSIGHTS FROM MACRO- AND OPTION-BASED MODELS}

Public debt management is essentially an ALM problem. This paper introduces a novel ALM methodology, the ALM compound option model, and contributes to the establishment of a sound analytical foundation for public debt management. As an illustration, the model is used to analyze the risk profile and sustainability of Australia's public debt and unfunded superannuation liabilities.

The ALM compound option model is based on the pricing model for compound options introduced by Geske (1977). As in the simpler one-period option-based models, the basic intuition underlying the model is that the value of the public sector net worth in a multiperiod setting is equivalent to the value of an option on an option on the total assets the government holds. We argue below, however, that the compound option pricing model is better suited for analyzing and evaluating the risk profile of a sovereign's public debt than some of the one-period option-based models currently being used or proposed in multilateral and national agencies. 


\section{A. Advantages Over One-Period Option-Based Models}

Why is the compound option approach an appropriate framework for public debt management? One-period option-based models, following on from the commercial success of Moody's KMV in modeling the credit risk of corporate issuers, attempt to extend the insights derived from the capital structure of a corporate issuer to a sovereign issuer. These models are built on the work of Black and Scholes (1973) and Merton (1974), and assume that there is only one debt payment, which is proxied by short-term debt plus a percentage of long-term debt.

While this first generation of models may have yielded insights into the factors that affect the default risk of public debt, its implications for the analysis of public debt are hampered by difficulties in the definition and measurement of the net worth of the public sector. Namely, in the case of corporate issuers, it is possible to infer the assets of the firm by using its equity price value and volatility. But this is not the case for the public sector. In addition, practical public debt management requires examination of the cash flow and currency composition structure of the debt profile. ${ }^{3}$ Thus, the original terms of the debt contracts are not secondary factors in the risk analysis of a given debt profile. As a consequence, one-period approximations may be impractical for applications, technical assistance, or even policy advice.

In the ALM compound option model, the one-period restriction is relaxed, because the debt maturity and the timing of the cash flows associated with interest rate and principal payments are explicitly accounted for in the model. ${ }^{4}$ In this multi-period setup, the debt issuer has the option to default at every debt repayment period. The decision to default depends on whether the call option on the asset value of the firm held by the debt issuer, or the net worth of the debt issuer, is "out- of-the-money." In contrast to one-period models, the value of the call option in any period depends on the value of the call options in subsequent periods. Exercising the call option, or not defaulting, is equivalent to buying back the debt from debt holders at face value. In the context of public debt management, the net worth of the debt issuer is equivalent to the expected value of the current and future resources available to the debt agency to service the debt in a timely manner.

The ALM compound option model, therefore, bypasses the problems associated with oneperiod option-based models by focusing on the cash flow aspects of the debt profile from an ALM perspective rather than by attempting to stretch the corporate capital structure analogy

\footnotetext{
${ }^{3}$ For instance, short-term debt can be rolled over.

${ }^{4}$ While the intuition builds on the Geske (1977) model, his closed form solution to the two-period problem cannot accommodate realistic debt profiles. We extend the model setup to a multiperiod setting and solve it numerically by using the Least Squares Monte Carlo (LSMC) simulation (Longstaff and Schwartz, 2001).
} 
to a sovereign issuer. The inclusion of the time dimension in the ALM compound option model can help debt managers to identify, monitor, and control the risks associated with different fiscal policy stances. Therefore, debt managers can use the ALM compound option model to assess whether the asset growth rate associated with a primary surplus is consistent with asset and liability matching needs.

\section{B. Advantages Over Macro-Based Models}

The ALM compound option model combines the best features of both the standard macroeconomic approach to debt sustainability and the one-period option-based models. Like the macroeconomic approach, our model also takes into account the intertemporal nature of the debt structure and defines public debt as sustainable, if the growth and proceeds from total assets are enough to finance future coupon and principal payments.

However, our model is an improvement not only on option-based models, but also on the macroeconomic approach, since it uses market information from the market prices of government securities, or other assets and liabilities, to derive the risk-neutral default probabilities of a given debt profile. Finally, the compound option approach is flexible enough to incorporate other extensions, such as stochastic interest rates, stochastic volatility, and jumps, as we explain in detail below.

\section{The Government BALAnCe Sheet ANd Net Worth}

In this section, we explain how to construct a measure of the public sector repayment capacity that is consistent with the definition of public sector net worth given in the 2001 IMF GFS Manual, and the definition of the public sector intertemporal budget constraint presented in Easterly and Yuravlivker (2000).

The 2001 IMF GFS Manual emphasizes that the public sector net worth should be the "preferred measure" for fiscal sustainability analysis. The 2001 GFS Manual, which is consistent with the United Nations' National System of Accounts, defines net worth as the difference between assets and liabilities at market prices and includes both financial and nonfinancial assets and liabilities. Changes in net worth occur as a result of (i) budgetary transactions, such as the collection of taxes, social contributions, grants, and other revenues, or the payment of salaries, goods, subsidies, grants, social benefits, interest, depreciation, and

other expenses; (ii) price effects (holding gains); and (iii) changes in the volume of assets and liabilities other than from transactions that may arise from exceptional events (earthquakes, floods, wars), normal events (natural resource discoveries and depletions, etc.), and account reclassifications. 
Easterly and Yuravlivker (2000) use a definition of the public sector intertemporal budget that is consistent with the concept of net worth outlined in the 2001 IMF GFS Manual. Table 1 below shows what asset and liability items are included in the public sector balance sheet.

Table 1. Public Sector Balance Sheet

\begin{tabular}{|l|l|}
\hline \multicolumn{1}{|c|}{ Assets } & \multicolumn{1}{|c|}{ Liabilities } \\
\hline $\begin{array}{l}\text { Government-owned public goods } \\
\text { (infrastructure, schools, heal th clinics, etc. } \\
\text { that generate an adequate ERR and an } \\
\text { indirect ERR through tax collection) }\end{array}$ & Public external debt \\
\hline $\begin{array}{l}\text { Government-owned capital that is } \\
\text { financially profitable (anything for which } \\
\text { government can charge user fees to } \\
\text { generate adequate ERR) }\end{array}$ & Public domestic debt \\
\hline $\begin{array}{l}\text { Value of government-owned natural } \\
\text { resource stocks (oil, minerals, etc.) }\end{array}$ & $\begin{array}{l}\text { Domestic contingent liabilities (e.g. bank } \\
\text { deposit guarantees, net present value of } \\
\text { pension scheme, guarantees of private debt) }\end{array}$ \\
\hline $\begin{array}{l}\text { Expected present value of loans to private } \\
\text { sector }\end{array}$ & Government's net worth \\
\hline $\begin{array}{l}\text { Source: Easterly and Yuravlivker (2000). } \\
1 / \text { ERR stands for economic rate of return. }\end{array}$
\end{tabular}

In addition to the financial and nonfinancial assets and liabilities, the balance sheet also includes contingent liabilities arising from deposit insurance, pension fund schemes, and government debt guarantees to the private sector. ${ }^{5,6}$ The public sector intertemporal budget constraint then requires that the present value of the operating balance, which is government expenditures minus revenues but excluding interest revenues and expenses, be less or equal to the government's net worth.

The previous definitions of the public sector balance sheet and associated budget constraint allow us to identify taxpayers as the government's shareholders. As mentioned above, taxes are an important source of increase in the government's net worth. Therefore, they are equivalent to an increase in the participation of taxpayers in the public sector equity through retained earnings. On the other hand, whenever the government buys goods and services or grants subsidies to taxpayers (or to society, in general), net worth declines accordingly as if dividends were distributed to taxpayers. In addition, in the hypothetical case that the government was to be liquidated, the remaining resources, after selling government assets and repaying bondholders and banks, would be used to continue providing goods, services,

\footnotetext{
${ }^{5}$ One can also include contingent assets, such as credit lines to the private sector, in the government balance sheet.

${ }^{6}$ In Australia, contingent assets and liabilities are publicly disclosed in the Budget and Mid-Year Economic and Fiscal Outlook under Australia's Charter of Budget honesty, but due to their uncertain nature, are not recorded on the balance sheet.
} 
and subsidies to taxpayers. Thus, taxpayers are the residual claimants or government shareholders. ${ }^{7}$

Because taxpayers are the government shareholders, both domestic and external debts should be considered in the public sector debt sustainability and asset and liability management analysis. Identifying domestic bondholders as residual claimants is incorrect and can lead to an underestimation of the health of the government's financial condition. Furthermore, foreign investors' increased risk appetite for domestic debt instruments and easier market access have enabled countries to increase the outstanding stock of domestic debt. Finally, if we are also interested in the burden on taxpayers arising from the debt service, it is wrong to consolidate the central bank and central government balance sheets for debt sustainability analysis and asset and liability management. Such a consolidation excludes the domestic and foreign debt holdings of the central bank and underestimates the risk of the public debt composition.

\section{The ALM COMPOUNd OPTION MODEL}

This section describes the ALM compound option model that is suitable for asset-liability management, debt sustainability analysis, and the measurement of the credit risk of the public sector balance sheet, among other applications. The model extends the Geske (1977) two-period model for valuing corporate liabilities as a compound option to a multi-period setting. To facilitate the reader's understanding of the model, a nontechnical discussion of the two-period compound option model of Geske is presented next, followed by a full discussion of the two-period model.

\section{A. Model Intuition}

Debt with multiple payments can be viewed as a compound option, or in other words, as an option on an option. Starting with Black and Scholes (1973) and Merton (1974), it has been recognized that the equity value of a leveraged firm is equivalent to a call option on the value of the firm's assets, where the strike price is associated with the face value of the debt owed by the firm. Geske (1977) and Geske and Johnson (1984) generalize this intuition by allowing multi-period debt payments. For simplicity, this section focuses on a two-period setting and assumes that no new debt is issued while existing debt is outstanding.

Let $M_{1}$ and $M_{2}$ be the coupon and coupon and principal payments at dates $T_{1}$ and $T_{2}$ respectively, and $V_{t}$ the value of the government's assets, where $t<T_{1}<T_{2}$. Note that the value of the taxpayer's equity at date, $S_{t}$, is an option on an option. At date $T_{2}$, the government has

\footnotetext{
${ }^{7}$ Reality has been more complex in debt restructurings. Bondholders and taxpayers have both shared the debt burden in restructuring processes. Debt restructuring has usually been conditioned on the adjustment programs as taxes are raised and expenditures reduced.
} 
the option not to default on its debt obligations if the market value $V_{2}$ is larger than the coupon and principal payments $M_{2}$. At date $T_{1}$, this option of not defaulting at date $T_{2}$ has a present value equivalent to $C\left(V_{1}\right)$, which is a function of the market value $V_{1}$ of the government's total assets. The government will also have the option not to default at date $T_{1}$ if the present value $C\left(V_{1}\right)$ is larger than the debt payments $M_{1}$; otherwise, the present value $C\left(V_{1}\right)$ will be worth less than the debt payments $M_{1}$ at date $T_{1}$.

Finally, the option of not defaulting at date $T_{1}$ has a present value equal to $C\left(V_{\mathrm{t}}\right)$ at date $t$, which is the market value of the taxpayers' equity and a function of the current value $V_{\mathrm{t}}$ of the government's assets. At date $T_{1}$, bondholders receive either the coupon payment $M_{1}$ and the present value of the remaining cash flows of the underlying bond. At date $T_{2}$, bondholders receive either the coupon and principal payment $M_{2}$ or the value of taxpayers' equity. After the coupon principal payment $M_{2}$ at date $T_{2}$, the value of government assets accrues entirely to taxpayers. Note that the model assumes that no new debt is issued while existing debt is outstanding.

The compound option model of Geske (1977) requires that the process governing the market value $V_{\mathrm{t}}$ of the government's total assets be continuous at any point in time. In the two-period setting above, this implies that, on the first expiration day $T_{1}$, the coupon payment $M_{1}$ is refinanced by extranet retained earnings. In this case, default arises as the government cannot raise enough taxes or reduce expenditures to finance the coupon or principal payments. Thus, whether or not the government defaults is intrinsically linked to its power to tax.

The risk profile in the two-period setting is summarized by the government's probabilities of default. The term structure of risk-neutral default probabilities $P D\left(T_{1}\right)$ and $P D\left(T_{2}\right)$ in a twoperiod setting indicates the likelihood that the government would default on its obligations at date $T_{1}$ and at either dates $T_{1}$ or $T_{2}$, respectively. The one-period forward risk-neutral probability of default $P D\left(T_{2} \mid T_{1}\right)$ is the probability that the government defaults between dates $T_{1}$ and $T_{2}$ conditional on not having defaulted at date $T_{1}$.

\section{B. The ALM Compound Option Model: The Two-Period Case}

\section{Pricing government liabilities}

Geske (1977) and Geske and Johnson (1984) offer an analytical solution to the compound option and, therefore, the value of the taxpayers' equity, $S_{t}$. We assume that changes in the value of total government assets are in line with changes in real GDP and asset prices. The former has unit roots while the latter is a random walk. 
Therefore, under a risk-neutral probability measure, the value of the government's assets, $V_{t}$, follows a stochastic differential equation given by:

$$
\frac{d V_{t}}{V_{t}}=r d t+\sigma d W_{t}
$$

where $r$ is the constant risk-free interest rate, $\sigma$ is the instantaneous variance of the value of government's total assets, and $W_{t}$ is a standard Wiener process. The assumption of a constant risk-free interest rate implies that the model has only one risk factor. Models with stochastic interest rates include Chen (2003), and Frey and Sommer (1998).

The analytical solution for the taxpayers' equity value can then be written as:

$$
S_{t}=V_{t} N_{2}\left(k_{1}+\sigma \sqrt{T_{1}-t}, k_{2}+\sigma \sqrt{T_{2}-t}, \rho\right)-M_{1} e^{-r\left(T_{1}-t\right)} N\left(k_{1}\right)-M_{2} e^{-r\left(T_{2}-t\right)} N_{2}\left(k_{1}, k_{2}, \rho\right),
$$

where $t<T_{1}<T_{2}$ and:

$$
\begin{aligned}
& k_{1}=\frac{\ln \left(V_{t} / \bar{V}\right)+\left(r-\sigma^{2} / 2\right)\left(T_{1}-t\right)}{\sigma \sqrt{T_{1}-t}}, \\
& k_{2}=\frac{\ln \left(V_{t} / M_{2}\right)+\left(r-\sigma^{2} / 2\right)\left(T_{2}-t\right)}{\sigma \sqrt{T_{2}-t}}, \\
& \rho=\sqrt{\frac{T_{1}-t}{T_{2}-t}},
\end{aligned}
$$

$N($.$) is the standard cumulative normal distribution function, N_{2}($.$) is the standard cumulative$ bivariate normal distribution function, $\rho$ is a correlation coefficient, and $\bar{V}$ is the value of government's total assets such that:

$$
S_{1}(\bar{V})-M_{1}=\bar{V} N\left(k_{2}+\sigma \sqrt{T_{2}-T_{1}}\right)-M_{2} e^{-r\left(T_{2}-T_{1}\right)} N\left(k_{2}\right)-M_{1} .
$$

As mentioned above, the first coupon payment $M_{1}$ is refinanced by the issuance of new equity on the first expiration day $T_{1}$. This is equivalent to extra retained earnings or new taxes in a public sector context and implies no drop in the market value $V_{1}$ of the government's total assets, remaining continuous across $T_{1}$ as required for the existence of an analytical solution. While the government might issue new debt to finance the debt service, it would only change the debt maturity profile. Default with respect to coupon and principal payments means that the government cannot raise enough taxes to finance the debt service. 
Along the same lines, analytical solutions to the market values of coupon and principal payments $M_{1}$ and $M_{2}$ can also be derived from the previous equations and the balance sheet constraint. The value at date $t$ of the coupon and principal payments $M_{1}$ at date $T_{1}, B_{1, t}$, is equal to the sum of its discounted value and the discounted expected value of the government's total assets if the coupon payment $M_{1}$ is not paid:

$$
B_{1, t}=M_{1} e^{-r\left(T_{1}-t\right)} N\left(\bar{d}_{2}\right)+V_{t} N\left(-\bar{d}_{1}\right) \text {, }
$$

where:

$$
\begin{aligned}
& \bar{d}_{1}=\frac{\log \left(V_{t} / M_{1}\right)+\left(r+\sigma^{2} / 2\right)\left(T_{1}-t\right)}{\sigma \sqrt{T_{1}}}, \\
& \bar{d}_{2}=\bar{d}_{1}-\sigma \sqrt{T_{1}-t}
\end{aligned}
$$

In turn, the value, $B_{2, t}$, at time $t$ of the principal payment $M_{2}$ is the sum of its discounted value given that there is no default at $T_{1}$ and $T_{2}$, the discounted expected value of the government's total assets in case of default, and any payment at time $T_{1}$ after the coupon payment $M_{1}$ is paid out:

$$
\begin{aligned}
B_{2, t}= & M_{2} e^{-r\left(T_{2}-t\right)} N_{2}\left(k_{1}, k_{2}, \rho\right)+V_{t} N_{2}\left(k_{1}+\sigma \sqrt{T_{1}-t},-k_{2}-\sigma \sqrt{T_{2}-t},-\rho\right) \\
& +V_{t}\left[N\left(-k_{1}-\sigma \sqrt{T_{1}-t}\right)-N\left(-\bar{d}_{1}\right)\right]-M_{1} e^{-r\left(T_{1}-t\right)}\left[N\left(\bar{d}_{2}\right)-N\left(k_{1}\right)\right] .
\end{aligned}
$$

The market value of total coupon and principal is given by the sum of $B_{1, t}$ and $B_{2, t}$ :

$$
\begin{aligned}
B_{1, t}+B_{2, t} & =V_{t}\left[1-N_{2}\left(k_{1}+\sigma \sqrt{T_{1}-t}, k_{2}+\sigma \sqrt{T_{2}-t}, \rho\right)\right] \\
& +M_{1} e^{-r\left(T_{1}-t\right)} N\left(k_{1}\right)+M_{2} e^{-r\left(T_{2}-t\right)} N_{2}\left(k_{1}, k_{2}, \rho\right) .
\end{aligned}
$$

The first term on the right-hand side is the recovery value after default. ${ }^{8}$ When default is a remote event, this term is close to zero and total debt is the sum of the present value of coupon and principal payments $M_{1}$ and $M_{2}$ adjusted by the survival probabilities. When default is a possible event, the second term kicks in. However, since governments cannot be liquidated and assets cannot be seized, this second term does not represent a source of value for debt holders. Indeed, this might explain why large discounts in government bonds are observed close to default. ${ }^{9}$

\footnotetext{
${ }^{8}$ See Altman et al (2003).

${ }^{9}$ The analysis does not factor in some potential costs to the debtor associated with default such as loss of market access for a prolonged period of time following the default.
} 
If governments do not issue subordinated debt, equation (6) can be used to price bonds and liabilities with different maturities. Given the survival probabilities $N($.$) and N_{2}(.$, .) and the risk-free interest rate $r$, a particular bond can be priced as the sum of its discounted cash flows adjusted by the survival probabilities and its corresponding share in the first term on the right-hand side of equation (6). This share can be proportional to the bond's contribution to the present value of total debt cash flows.

\section{The risk premium}

Rearranging terms in expressions (5) and (6) yields the risk premium structure. ${ }^{10}$ For the first period, the risk premium is:

$$
R_{1, t}-r=-\frac{1}{T_{1}} \log \left(N\left(\bar{d}_{2}\right)+\frac{V_{t}}{M_{1} e^{-r\left(T_{1}-t\right)}} N\left(-\bar{d}_{1}\right)\right)
$$

while, for the second period, the risk premium is given by:

$$
\begin{aligned}
R_{2, t}-r & =-\frac{1}{T_{2}} \log \left(N_{2}\left(k_{1}, k_{2}, \rho\right)+\frac{V_{t}}{M_{2} e^{-r\left(T_{2}-t\right)}} N_{2}\left(k_{1}+\sigma \sqrt{T_{1}-t},-k_{2}-\sigma \sqrt{T_{2}-t},-\rho\right)\right. \\
& \left.+\frac{V_{t}}{M_{2} e^{-r\left(T_{2}-t\right)}}\left[N\left(-k_{1}-\sigma \sqrt{T_{1}-t}\right)-N\left(-\bar{d}_{1}\right)\right]-\frac{M_{1} e^{-r\left(T_{1}-t\right)}}{M_{2} e^{-r\left(T_{2}-t\right)}}\left[N\left(\bar{d}_{2}\right)-N\left(k_{1}\right)\right]\right) .
\end{aligned}
$$

\section{Risk-neutral probabilities of default}

Equations (2) to (5) above are used to derive the term-structure of risk-neutral probabilities of default and the one-period forward risk-neutral probabilities of default. ${ }^{11}$ The term structure consists of the joint probability $P D^{Q}\left(T_{2}\right)$ of defaulting either on the first or the second maturity dates $T_{1}$ or $T_{2}$ :

$$
P D^{Q}\left(T_{2}\right)=1-N_{2}\left(k_{1}, k_{2} ; \rho\right)
$$

where $Q$ indicates under the risk-neutral probability measure. The short-term marginal probability $P D^{Q}\left(T_{1}\right)$ of defaulting on the first maturity day $T_{1}$ is given by:

\footnotetext{
${ }^{10}$ See Merton (1974).

${ }^{11}$ See Delianedis and Geske (2003) for more details.
} 


$$
P D^{Q}\left(T_{1}\right)=1-N\left(k_{1}\right) \text {. }
$$

Finally, the one-period forward probability $P D^{Q}\left(T_{2} \mid T_{1}\right)$ of defaulting on the second maturity day $T_{2}$ conditional on not defaulting on the first maturity day $T_{1}$ is equal to:

$$
P D^{Q}\left(T_{2} \mid T_{1}\right)=1-\frac{N_{2}\left(k_{1}, k_{2} ; \rho\right)}{N\left(k_{1}\right)}
$$

\section{Real-world probabilities of default}

The previous default probabilities are defined under a risk neutral probability measure. This implies that, if investors are risk averse, worst outcomes have a higher probability than under a real-world probability measure and vice-versa. While risk-neutral probability distributions should be used for pricing, real world probability distributions should be used in carrying out scenario analysis. ${ }^{12}$

If the market price of risk for an asset, or its Sharpe ratio, is known, real world probability distributions can be derived. The market price of risk $\lambda$ is defined as the price per unit of risk investors require for holding a risky security:

$$
\frac{\mu-r}{\sigma}=\lambda
$$

where $\mu$ is the instantaneous expected return on the government's total assets.

The latter equation is similar to the capital asset pricing model (CAPM), which predicts that the expected excess return on an asset should reward investors for the systemic risk that cannot be diversified away. The expected excess return on the government's total assets would then be proportional to the market's expected excess return:

$$
\mu-r=\beta_{V, M}\left(\mu_{M}-r\right)
$$

where $\beta_{V, M}$ is the ratio of the covariance between the return on the government's total assets and the market return to the market variance, and $\mu_{M}$ is the market's expected return. Equations (12) and (13) imply that the expected excess return on the government's total assets is proportional to the market Sharpe ratio $\lambda_{M}$. In addition, the market price of risk $\lambda$ for the government's total assets is given by:

${ }^{12}$ See Hull (2008). 


$$
\frac{\mu-r}{\sigma}=\rho_{V, M} \lambda_{M}
$$

where $\rho_{V, M}$ is the correlation between the return on the government's total assets and the market return. This is an arbitrage condition that is not dependent on the maturity profile. Therefore, there should be no scaling factor accounting for maturity effects in the pricing of government liabilities or any other liability.

Given the market price of risk for the government's total assets, the real-world probabilities of default can then be obtained by a change in the probability measure as illustrated by Duffie and Singleton (2003). Note that a binormal distribution can also be written as the product of a marginal and a conditional distribution and that the inverse of multi-normal distributions is not defined. ${ }^{13}$ The change in the probability measure is first obtained for the marginal distribution:

$$
P D^{P}\left(T_{1}\right)=1-N\left(N^{-1}\left(N\left(k_{1}\right)\right)+\left(\frac{\mu-r}{\sigma}\right) \sqrt{T_{1}-t_{1}}\right)
$$

and then for the conditional distribution:

$$
P D^{P}\left(T_{2} \mid T_{1}\right)=1-N\left(N^{-1}\left(\frac{N\left(k_{1}, k_{1} ; \rho\right)}{N\left(k_{1}\right)}\right)+\left(\frac{\mu-r}{\sigma}\right) \sqrt{T_{2}-T_{1}}\right)
$$

where $P D^{P}$ is the probability of default under the real-world measure. The multiplication of both expressions yields the real-world joint probability of default.

\section{Greeks and sensitivity analysis}

Geske (1977) also derives the sensitivity of the market value of the taxpayers' equity $S_{t}$ to changes in the option parameters. Table 2 below summarizes his results. The market value $S_{t}$ rises in response to an increase in the market value of the government's total assets $V_{\mathrm{t}}$ and its volatility $\sigma$, the risk-free interest rate $r$, and the two expiration days $T_{1}$ and $T_{2}$. On the other hand, the market value, $S_{t}$, declines as the payments $M_{1}$ and $M_{2}$ increase.

\section{Solving the ALM Compound Option Model}

The multi-period ALM compound option model is solved using the Least Squares Monte Carlo (LSMC) simulation method. This solution method yields the equity value, the term

\footnotetext{
${ }^{13}$ See Lajeri-Chaherli (2002).
} 
structure of default probabilities and the one-year default probabilities corresponding to the debt profile. Furthermore, finite difference approximations can be used to derive the sensitivity of the results, especially default probabilities, to changes in the model parameters, as explained in Glasserman (2004).

The LSMC simulation method is based on the fact that, in Monte Carlo simulations, the unconditional expectation of the continuation value of a compound option can be determined by exploiting the cross-sectional information of the simulations using least squares. ${ }^{14}$ This method is akin to projecting the option payoffs on a set of orthogonal bases. In the multiperiod compound option model, the procedure can be repeated backwards for each Monte Carlo path from the maturity date up to the initial period to find the optimal stopping times and continuation values, and averaging across the latter yields the option price.

\section{Table 2. Greeks for Compound Options}

$$
\begin{aligned}
& \partial S_{t} / \partial V_{t}=N_{2}\left(k_{1}+\sigma \sqrt{T_{1}-t}, k_{2}+\sigma \sqrt{T_{2}-t} ; \sqrt{\left(T_{1}-t\right) /\left(T_{1}-t\right)}\right)>0, \\
& \partial S_{t} / \partial M_{2}=-e^{-r\left(T_{2}-t\right)} N_{2}\left(k_{1}, k_{2} ; \sqrt{\left(T_{1}-t\right) /\left(T_{1}-t\right)}\right)<0, \\
& \partial S_{t} / \partial M_{1}=-e^{-r\left(T_{1}-t\right)} N\left(k_{1}\right)<0, \\
& \frac{\partial S_{t}}{\partial r}=\frac{N_{2}(\cdot)}{N\left(k_{2}+\sigma \sqrt{T_{2}-t}\right)} M_{2}\left(T_{2}-t\right) e^{-r\left(T_{2}-t\right)} N\left(k_{2}\right)>0, \\
& \frac{\partial S_{t}}{\partial \sigma^{2}}=\frac{N_{2}(\cdot)}{N\left(k_{2}+\sigma \sqrt{T_{2}-t}\right)} M_{2} e^{-r\left(T_{2}-t\right)} N^{\prime}\left(k_{2}\right) \frac{\sqrt{T_{2}-t}}{2 \sigma}>0, \\
& \frac{\partial S_{t}}{\partial T_{2}}=\frac{N_{2}(\cdot)}{N\left(k_{2}+\sigma \sqrt{T_{2}-t}\right)} M_{2} e^{-r\left(T_{2}-t\right)}\left[N^{\prime}\left(k_{2}\right) \frac{\sigma}{2 \sqrt{T_{2}-t}}+r N\left(k_{1}\right)\right]>0, \\
& \frac{\partial S_{t} / \partial T_{1}>0 .}{}
\end{aligned}
$$

Source: Geske (1977)

In contrast to plain Monte Carlo simulations, the LSMC simulation method is not affected by the high bias problem. The bias arises from the fact that plain Monte Carlo simulation only samples paths for which continuation is an optimal strategy. Or in other words, this method implies knowing the future and leads to a super-optimal exercising strategy. The high bias

\footnotetext{
${ }^{14}$ See Gamba (2002) and Areal, Rodrigues, and Armada (2009).
} 
problem can be alleviated using stochastic mesh methods, such as the LSMC simulation method, that interleave both high-bias and low-bias estimators. ${ }^{15}$

\section{The Role of Fiscal Policy and Asset and Liability Management}

Fiscal policy and asset and liability management can have a direct impact on the pricing of government liabilities and fiscal sustainability. The budget process and execution can affect net worth $S_{t}$ and total assets $V_{t}$ directly. For instance, if the government plans to raise taxes (or increase expenditures) in the budget, it will trigger an increase (a decline) in net worth, total assets, and the market value of its liabilities, and a decline (an increase) in the probabilities of default. In turn, the role of asset and liability management is to ensure that the government's total assets are allocated to the most adequate risk-return combination. A particularly important case concerns the ability of the government to change its future revenue and/or expenditure patterns. From the discussion of the net worth of the government in section III, an increase in the ability of the government to generate additional revenues, or similarly, a sustained reduction in the flow of government expenditures, is equivalent to a reduction of paid dividends. Therefore, as is usual in option pricing models, the risk-free rate should be adjusted downwards by the implicit dividend rate. The end result is that increased revenues and/or reduced government expenditures are reflected in a higher risk-free rate and translate into lower risk-neutral default probabilities.

\section{APPlication to Australia's Government DEBT AND UNFUnded SUPERANNUATION LIABILITIES}

In this section, we analyze the debt sustainability and ALM of the Commonwealth of Australia, as of end-June 2008. Australia has used accrual accounting and implemented a methodology similar to the 2001 IMF GFS Manual since 1999. Assets in Australia's balance sheets are generally recorded at their fair value. ${ }^{16}$ In addition, assessing the risks to its balance sheets is an important input for the formulation of the government's fiscal policy. As a result of sound fiscal policy and cautious public debt management, Australia's sovereign debt is rated "Aaa" by Moodys.

From publications available on the web, we use annual data on Australia's balance sheets, operating balances, domestic and external debts, and superannuation benefits. ${ }^{17}$ However, we

\footnotetext{
${ }^{15}$ See Broadie and Glasserman (2004).

${ }^{16}$ Where applicable, a fair value (or market value) methodology is used to record the value of financial and nonfinancial assets on the balance sheet; however, in some cases, this methodology is not possible and an 'at cost' valuation methodology is applied.

${ }^{17}$ The Australian public sector consists of the Commonwealth general government, public financial and nonfinancial corporates. Our analysis focuses only on the Commonwealth general government.
} 
also make assumptions and approximations related to the projections for debt service items and superannuation benefits, as not all necessary information is available in the publications. Therefore, the results in the text are only illustrative of how the ALM compound option model can be used in debt sustainability analysis and for asset and liability management.

The liabilities of Australia are characterized by a large share of unfunded superannuation liabilities and a low stock of outstanding debt. As indicated in Table 3, government securities and employment entitlements - mainly unfunded superannuation liabilities - represented 21 percent and 40 percent of total assets, respectively, at end June-2008. Projections for the debt service (before any derivatives effects) and superannuation benefits are plotted in Figure $1 .^{18}$ Debt payment and superannuation benefit dates range, respectively, from 2009 to 2013 (12 fiscal years) and from 2009 to 2104 (96 fiscal years). ${ }^{19}$ The domestic debt included treasury bonds, treasury indexed bonds (with an inflation growth assumption of 2.5 percent per year), while the external debt consisted mainly of U.S. dollar-denominated loans converted into Australian dollars at the end-June 2008 exchange rate. However, the foreigncurrency denominated debt represented only 0.01 percent of total debt.

\section{Table 3. Australia: Commonwealth Balance Sheet, June 2008}

(In billions of Australian dollars)

\begin{tabular}{lcc}
\hline & AU \$ billion & Percent \\
\hline Total assets & 272.8 & 100.0 \\
Financial as sets & 183.7 & 67.4 \\
Non-financial assets & 89.0 & 32.6 \\
Liabilities & 205.5 & 75.3 \\
Government securities & 58.4 & 21.4 \\
Employee entitlements & 109.0 & 40.0 \\
Other liabilities & 38.0 & 13.9 \\
Net Worth & 67.3 & 24.7 \\
\hline
\end{tabular}

Source: Commonwealth of Australia (2009).

The Australian government has taken a proactive stance in its asset and liability management. Between 1997 and 2007, it used interest rate swaps to manage the risks associated with duration and short-dated exposure of the portfolio. ${ }^{20}$ At end-June 2008, the principal notional

\footnotetext{
${ }^{18}$ We developed a model to project the unfunded superannuation benefit payments. The profile of the projected present value of the benefit payments during 2009-2050 in our model is similar to the one contained in the 2008 Commonwealth budget and in Commonwealth of Australia (2009b and c).

${ }^{19}$ Quarterly or monthly projections would have been possible also, if debt service projections were prepared accordingly.

${ }^{20}$ The swap program was guided by benchmark parameters set in annual reviews and resulted in savings of around AU\$2 billion to the Australian Government over the period. These savings were largely the result of a positive term premium between market rates on longer and shorter term debt. During this period, the
} 
amount of interest rate swaps used to hedge against market risk was about AU\$ 23 billion and was not booked as assets or liabilities but disclosed in the notes to the balance sheet. ${ }^{21}$

Australia has historically witnessed negative net worth. It has provided significant funding to states and local governments for capital works, with the resultant assets recorded in their balance sheets. However, Australia's net worth has experienced a consistent improvement since the late 1990s. With a few accounting changes that have been implemented recently, net worth has become positive since the 2004-05 fiscal year. In addition, part of the operating balance surpluses has been saved in the Future Fund and will be withdrawn either from 2020 or from the time the Fund's assets exceed its target asset level to match the increasing payments related to the unfunded superannuation benefits.

The market value of the government's total assets, $V_{t}$, and the market's volatility, $\sigma$, are not directly observable in financial markets and, therefore, need to be estimated. We assume that the risk-free interest rate $r$ over a year is equal to the 6 percent rate used in regulatory price determinations in Australia and that the annual debt service and unfunded superannuation benefit projections $M_{1}$ to $M_{96}$ for the period June 2008-June 2104 are given as in Figure 1 . As starting values in our calibration, we use the fair value of total assets $V_{t}$ in Australia's Commonwealth balance sheet and approximate its associated volatility $\sigma$ by the observed volatility in Australia's total assets. The fair value of total assets $V_{t}$ amounted to about AU\$ 272.7 billion in June 2008 and the Maximum Likelihood estimate for its standard deviation $\sigma$ in the period 2000-2008 was equivalent to 9.4 percent.

Equations (15) and (16) for the real-world probabilities of default require an estimate for the market price of risk. Brailsford, Handley, and Maheswaran (2008) estimate that the equity risk premium averaged 6.3 percent over 1958-2005 and that the standard deviation of the nominal return on stocks over the same period was 22 percent. The Maximum Likelihood estimate for the correlation between Australia's total assets and the Australian stock exchange (ASX) ordinary shares index during the period June 2000-June-2008 is 31.4 percent.

We use the LSMC simulation method by Schwartz and Longstaff (2001) to estimate the market value of taxpayers' equity, government securities, and unfunded superannuation liabilities, the term structure of probabilities of default under both the risk-neutral and real-

Government had a relatively static level of Government securities on issue so, in a historical cost sense, the execution of swaps actually added to the level of risk as it added an additional variable to debt servicing costs. However, on a marked-to-market basis, the execution of these swaps did reduce the amount of risk to the balance sheet. In the 2008 annual review of its portfolio, the Australian Office of Financial Management (AOFM) decided to cease entering into new interest rate swaps as a result of the declining term premium. Since that time, the AOFM has allowed existing interest rate swaps to mature as well as unwinding a portion of its existing swap book.

${ }^{21}$ See Commonwealth of Australia (2009a). 
world measures, and the associated one-year forward probabilities of default. Given the starting parameters for the market value of total assets and its volatility, we initially perform 100,000 Least Squares Monte Carlo (LSMC) simulations under two scenarios: (i) where government securities are the only liability with multiple maturities, and (ii) where both government securities and superannuation benefits have multiple maturities. The single risk factor that drives the pricing of government liabilities and fiscal sustainability is Australia's total asset growth. Table 4 summarizes the simulation results for the taxpayers' equity (net worth), government securities, and unfunded superannuation benefits under both scenarios and under different parameter and policy assumptions. Figure 2 plots the corresponding term structure of default probabilities and the one-year forward probabilities of default under the scenario where both government securities and superannuation benefits have multiple maturities. $^{22}$

\footnotetext{
${ }^{22}$ The term structure of default probabilities with government securities as the only liability with multiple maturities was flat and equal to zero. This is consistent with zero cumulative average sovereign default rates by Moodys.
} 
Figure 1. Australia: Commonwealth Debt Service and Superannuation Benefits, End-June 2009

(In billions of Australian dollars)
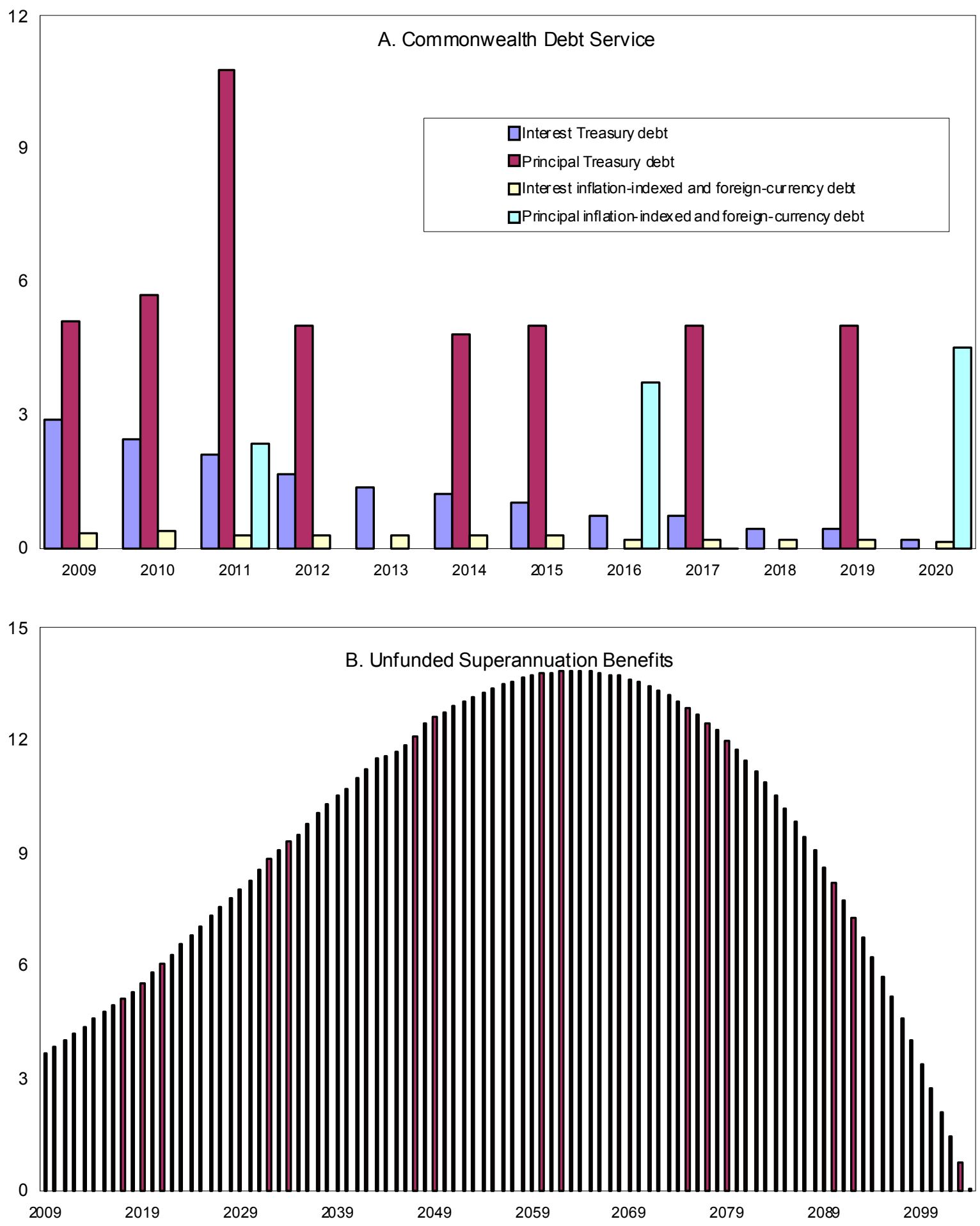

Source: Australian Office of Financial Management, Commonwealth of Australia (2009a and 2009b), and authors' calculations. 
Table 4. Australia: LSCM Simulation Results, June 2008

(In billions of Australian dollars)

A. Only Government Securities 1/

\begin{tabular}{|c|c|c|c|c|c|c|c|}
\hline Parameters/Model & Fair Value & Baseline & (1) & (2) & (3) & $(4)$ & (5) \\
\hline $\mathrm{V}_{\mathrm{t}}(\mathrm{AU} \$$ billion $)$ & & 125.7 & 125.7 & 125.7 & 98.4 & 125.7 & 125.7 \\
\hline$\sigma$ (percent) & & 9.4 & 10.0 & 9.4 & 9.4 & 9.4 & 9.4 \\
\hline$r$ (percent) & & 6.0 & 6.0 & 6.6 & 6.0 & 6.0 & 6.0 \\
\hline Maturity profile & & $M_{1}$ to $M_{12}$ & $M_{1}$ to $M_{12}$ & $M_{1}$ to $M_{12}$ & $M_{1}$ to $M_{12}$ & $1.1{ }^{*} M_{1}, M_{2}$ to $M_{12}$ & $M_{1.5}$ to $M_{12}$ \\
\hline Net assets & 125.7 & 125.7 & 125.7 & 125.7 & 98.4 & 125.7 & 125.7 \\
\hline Financial assets & 183.7 & 183.7 & 183.7 & 183.7 & 165.3 & 183.7 & 183.7 \\
\hline Non-financial assets & 89.0 & 89.0 & 89.0 & 89.0 & 80.1 & 89.0 & 89.0 \\
\hline - Employee entitlements & 109.0 & 109.0 & 109.0 & 109.0 & 109.0 & 109.0 & 109.0 \\
\hline - Other liabilities & 38.0 & 38.0 & 38.0 & 38.0 & 38.0 & 38.0 & 38.0 \\
\hline Liabilities & 58.4 & 57.2 & 56.9 & 55.4 & 57.1 & 57.9 & 56.7 \\
\hline Government securities & 58.4 & 57.2 & 56.9 & 55.4 & 57.1 & 57.9 & 56.7 \\
\hline Net Worth & 67.3 & 68.5 & 68.8 & 70.2 & 41.3 & 67.8 & 69.0 \\
\hline
\end{tabular}

B. Government Securities and Employee Entitlements 1/

\begin{tabular}{|c|c|c|c|c|c|c|c|}
\hline Parameters/Model & Fair Value & Baseline & (6) & (7) & (8) & (9) & $(10)$ \\
\hline$V_{t}(A \cup \$$ billion $)$ & & 234.7 & 234.7 & 234.7 & 207.4 & 234.7 & 234.7 \\
\hline$o$ (percent) & & 9.4 & 10.0 & 9.4 & 9.4 & 9.4 & 9.4 \\
\hline$r$ (percent) & & 6.0 & 6.0 & 6.6 & 6.0 & 6.0 & 6.0 \\
\hline Maturity profile & & $M_{1}$ to $M_{96}$ & $M_{1}$ to $M_{96}$ & $M_{1}$ to $M_{96}$ & $M_{1}$ to $M_{96}$ & $1.1^{*} M_{1}, M_{2}$ to $M_{96}$ & $M_{1.5}$ to $M_{96}$ \\
\hline Assets & 234.7 & 234.7 & 234.7 & 234.7 & 207.4 & 234.7 & 234.7 \\
\hline Financial assets & 183.7 & 183.7 & 183.7 & 183.7 & 165.3 & 183.7 & 183.7 \\
\hline Non-financial assets & 89.0 & 89.0 & 89.0 & 89.0 & 80.1 & 89.0 & 89.0 \\
\hline - Other liabilities & 38.0 & 38.0 & 38.0 & 38.0 & 38.0 & 38.0 & 38.0 \\
\hline Liabilities & 167.4 & 167.3 & 165.3 & 149.9 & 165.5 & 168.4 & 165.6 \\
\hline Government securities & 58.4 & 57.2 & 56.6 & 54.7 & 56.9 & 58.1 & 56.6 \\
\hline Employee entitlements & 109.0 & 110.1 & 108.7 & 95.1 & 108.5 & 110.3 & 109.0 \\
\hline Net Worth & 67.3 & 67.4 & 69.4 & 84.9 & 42.0 & 66.4 & 69.2 \\
\hline
\end{tabular}

Source: Commonwealth of Australia (2009a) and authors' calculations.

$1 /$ Liabilities with different maturity profiles. 
When government securities are the only liability with several maturities, the baseline model in panel A, Table 4, provides a reasonable approximation to the fair values of Australia's liabilities and equity. We assume that other liabilities, including unfunded superannuation liabilities, are senior to government securities or guaranteed by assets in the government's balance sheet. The remaining assets are then used to service the government debt during the 12 fiscal years. As predicted by Table 2, when the volatility of the government's total assets increases as in model 1 (third column in panel A, Table 4), the risk-free interest rate or the structural primary surplus (similar to the dividend yield) rises as in model 2 (fourth column in panel A, Table 4), or maturities are lengthened as in model 5 (seventh column in panel A, Table 4), the taxpayers' equity increases at the expense of a decline in the market value of government securities. When fiscal policy leads to a sudden increase in government expenditures and a simultaneous decline in the government's total assets as in model 3 (fifth column in panel A, Table 4), both the market value of government securities and the taxpayers' equity fall. On the other hand, when budgetary expenditures are financed by debt issuance as in model 4 (sixth column in Panel A, Table 4), the market value of government securities increases to the detriment of taxpayers' equity.

If superannuation benefits are also a liability with several maturities, the baseline scenario in panel B, Table 4, is also a good approximation to the fair value of government securities and unfunded superannuation liabilities. In this case, the government also holds an option not to default on the unfunded superannuation liability that has a positive value for the taxpayer. If matched by assets in Australia's Commonwealth balance sheets, superannuation benefits are exempt from default by the government. Panel B in Table 4 also indicates that, when the volatility of the government's total assets increases as in model 6 (third column in panel B, Table 4), the risk-free interest rate or the structural primary surplus (similar to the dividend yield) rises as in model 7 (fourth column in panel B, Table 4), or maturities are lengthened as in model 10 (seventh column in Panel B, Table 4), the market value of the superannuation benefits declines along with the market value of government securities. When fiscal policy leads to a decline in the government's total assets to finance government expenditures as in model 8 (fifth column in panel B, Table 4), the market value of superannuation benefits falls with both the market value of government securities and the taxpayers' equity. When budgetary expenditures are financed by debt issuance, as in model 9 (sixth column in panel B, Table 4), the market value of superannuation benefits and government securities increases.

Figure 2 illustrates how Australia's total assets would easily cover the required superannuation and debt payments. The probabilities of default, under the scenario where government securities are the only liability with a variety of maturities and under different parameter assumptions, are equal to zero. In spite of their sensitivity to parameter assumptions, the probabilities of default under the other scenario, where both government securities and superannuation liabilities have a large number of maturities, are positively sloped over the 10-year period and are in the range of close-to-zero to 3 percent. They were 
also below Moodys' cumulative sovereign default rates for investment grade borrowers and above both Moodys' corporate default rates for "Aaa" borrowers and the zero cumulative average sovereign default rates for "Aaa" borrowers. 
Figure 2. Australia: Commonwealth Probabilities of Default, End-June 2008 1/

(In percentage)
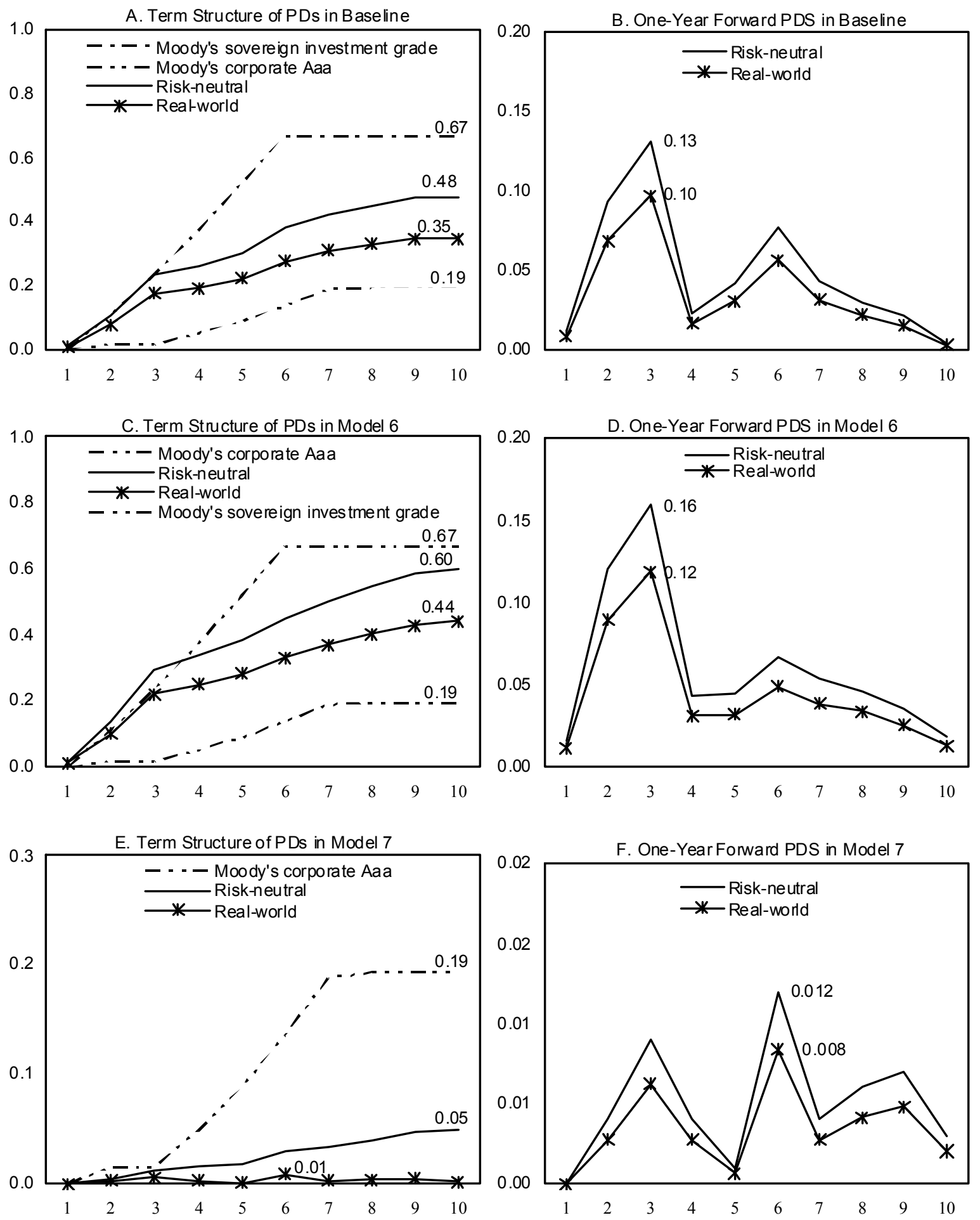
Continued...
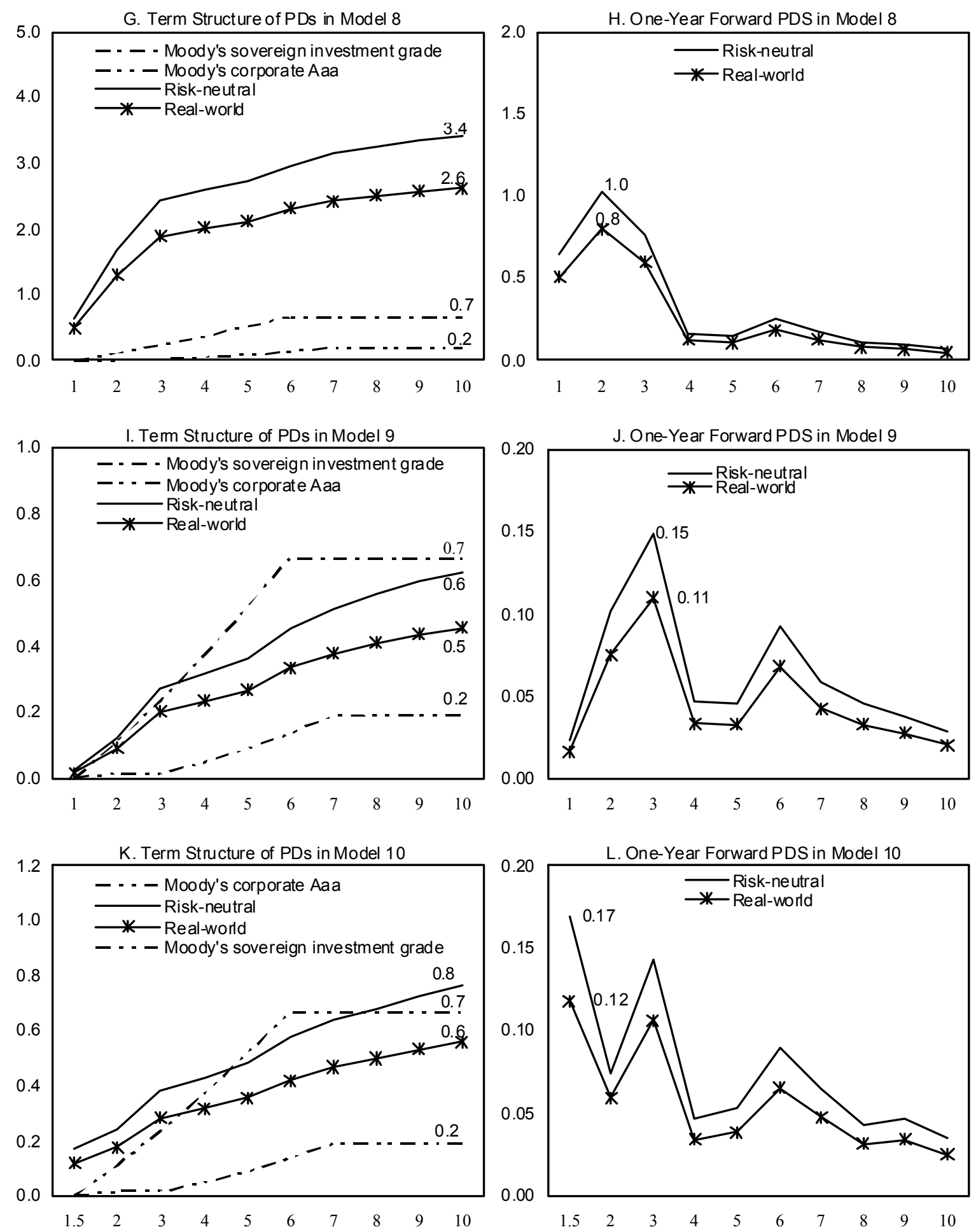

Source: Table 3, and authors' calculations.

$1 /$ The risk-neutral and real-world PDs for models 1 to 5 are equal to zero. 


\section{Conclusion}

Sound public debt management, especially during exit strategies after a large expansion involving debt financing, can only be accomplished if debt managers have the needed tools for understanding, measuring, and managing the risks associated with the government balance sheet. This paper proposes such a tool, the ALM compound option model. The model is useful not only for public debt management but also for debt sustainability analysis and, more generally, for asset-liability management in financial institutions and for fixed income investors interested in establishing price benchmarks for sovereign debt.

The ALM compound option model builds on the options approach to credit risk analysis and the intertemporal macroeconomic approach to debt sustainability. It goes beyond the standard option approach assumption of a single debt payment, since it accounts for the fact that sovereign debt profiles involve multiple debt payments. Specifically, our model builds on the compound options model of Geske (1977), where default can be interpreted as an option on an option to buy back the debt at each debt payment date at a discount. In contrast to the macroeconomic approach to debt sustainability, the ALM compound option model uses market information, as it incorporates the information contained in the market prices of sovereign debt. Finally, we want to note that the model can be extended easily in a number of directions to incorporate features such as stochastic interest and exchange rates and volatility, discontinuous prices, and extendible options.

One caveat is that not all countries have adopted the 2001 IMF GFS Manual, so estimates for the government's total assets at a fair value might not exist. In this case, the LSMC simulation method by Schwartz and Longstaff (2001) could be used in conjunction with the calibration method by McLeish (2005) to estimate the market value of the government's total assets and its volatility, and to simulate the market value of taxpayers' equity, the term structure of risk-neutral and real-world probabilities of default, and the one-year forward probabilities of default. Given the starting parameters for the market value of total assets and its volatility, LSMC simulations are performed and the market values of equity and total debt and probabilities of default are obtained. For small changes in the starting parameters, new LSMC simulations are run. The optimum estimates for the parameters are the ones that minimize the sum of the squared difference between the market value of total debt and the simulated value. 


\section{REFERENCES}

Altman, Edward I., Brooks Brady, Andrea Resti, and Andrea Sironi, 2003. "The Link between Default and Recovery Rates," New York University Working Paper, No. SCDM-04-07.

Areal, Nelson, Arthur Rodriguez, and Manuel J. R. Armada, 2009, "Improvements to the Least Squares Monte Carlo Option Valuation Method," Mimeo (Braga: University of Minho).

Black, Fisher and Myron Scholes, 1973, "The Pricing of Options and Corporate Liabilities," Journal of Political Economy, Vol. 81(May-June), pp. 637-54.

Brailsford, Tim, John C. Handley, and Krishnan Maheswaran, 2008, "Re-examination of the Historical Equity Risk Premium in Australia," Accounting \& Finance, 48(1), pp. 73-97.

Cassimon, D., P. J. Engelen, L. Thomassen, and M. Van Wouwe, 2004, "The Valuation of a NDA Using a 6-Fold Compound Option,” Research Policy, Vol. 33, pp. 41-51.

Chen, Ren-Raw, 2003, “The Extended Geske-Johnson Model and Its Consistency with Reduced Form Models," Mimeo.

Commonwealth of Australia, 2009a, Consolidated Financial Statements for the Year Ended 30 June 2008, (Canberra: Department of Finance and Deregulation).

, 2009b, PSS and CSS Long Term Cost Report 2008, (Canberra: Department of Finance and Deregulation).

, 2009c, Defence Force Retirement and Death Benefits Scheme (MSBS and DFRDB), (Canberra: Australian Government Actuary).

Delianedis, Gordon and Robert Geske, 2003, "Credit Risk and Risk Neutral Default Probabilities: Information about Rating Migrations and Defaults," EFA 2003 Annual Conference Paper No. 962.

Duffie, Darrell and Kenneth Singleton, 2003, Credit Risk: Pricing, Measurement and Management (Princeton: University of Princeton). 
Easterly, William and David Yuravlivker, 2000, Treasury or Time Bombs? Evaluating Government Net Worth in Colombia and Venezuela. (Washington: World Bank), mimeo.

Frey, Rüdiger and Daniel Sommer, 1998, “The Generalization of the Geske-Formula for Compound Options to Stochastic Interest Rates is not Trivial-A Note," Journal of Applied Probability, Vol. 35, pp. 501-9.

Gamba, Andrea, 2002, "Real Options Valuation: A Monte Carlo Simulation Approach," Mimeo, (Verona: University of Verona).

Geske, Robert, 1977, "The Valuation of Corporate Liabilities as Compound Options," Journal of Financial and Quantitative Analysis, Vol. 12(4), pp. 541-52.

, 1979, "The Valuation of Compound Options," Journal of Financial Economics, Vol. 7, pp. 63-81.

, and H. E Johnson, 1984, "The Valuation of Corporate Liabilities as Compound Options: A Correction," Journal of Financial and Quantitative Analysis, Vol. 19(2), pp. 231-2.

Hull, John, 2008, Options, Futures and Other Derivatives, $7^{\text {th }}$ edition, (New Jersey: Prentice Hall).

International Monetary Fund, 2002, Global Financial Stability Report (Washington: International Monetary Fund).

and International Bank for Reconstruction and Development, 2003, Guidelines for Public Debt Management (Washington: International Monetary Fund).

Lajeri-Chaherli, Fatma, 2002, “A Note on the Valuation of Compound Options," Journal of Futures Markets, Vol. 22(11), pp. 1103-15.

Longstaff, Francis A. and Eduardo S. Schwartz, 2001, "Valuing American Options by Simulation: a Simple Least-Squares Approach," Review of Financial Studies, Vol. $14(1)$, pp. 113-47.

Merton, Robert C., 1973, "Theory of Rational Optimal Pricing," Bell Journal of Economics and Management Science, Vol. 4 (Spring), pp. 141-83. 
, "On the Pricing of Corporate Debt: The Risk Structure of Interest Rates," Journal of Finance, Vol. 29(2), pp. 449-70.

Togo, Eriko, 2007, "Coordinating Public Debt Management with Fiscal and Monetary Policies: an Analytical Framework," World Bank Policy Research Working Paper, No. 4369 (September 2007). 